\title{
"MISTAKE" AND FORUM SHOPPING IN SUITS FOR REFUND OF FEDERAL TAX
}

A case recently decided by the Court of Appeals for the Second Circuit ${ }^{1}$ could have a significant impact on the pattern of forum shopping in federal tax litigation. Presently the taxpayer who decides to challenge an income, estate or gift tax assessment may choose among several courts: he may ask the Tax Court to redetermine the amount of tax due, or else he may pay the disputed assessment and sue for a refund either in the Court of Claims or in a district court. ${ }^{2}$ Each court has pectliar features, ${ }^{3}$ not the least important of which are its precedents. ${ }^{4}$ Taxpayers have long made the choice of a forum with advantageous precedents a standard part of their pre-trial strategy. 5 In the case recently before the Second Circuit, however, it was not the taxpayer but the government which had chosen a particular forum for strategic purposes.

The taxpayer, Russell Manufacturing Company, had established in a previous suit in the Court of Claims ${ }^{6}$ that, contrary to the relevant Treasury Regulation, ${ }^{7}$ distributions made by the trustee of the Company's nonqualified ${ }^{8}$ profit sharing plan to its beneficiaries were deductible expenses in the year distributed. The Internal Revenue Service thought that the decision was wrong and announced publicly that the issue would be relitigated in other cases. ${ }^{9}$ Nevertheless, in response to threats by Russell to bring suit again in the Court of Claims in connection with distributions made in years subsequent to those before the court in its initial determination, the Service made additional refunds to Russell. Subsequently, in an action in the Court of Claims involving another taxpayer, the government failed once more to convince that court that the Regulation was

1 United States v. Russell Mfg. Co., 349 F.2d 13 (2d Cir. 1965).

2 See, e.g., Gannett, Pre-Trial Strategy in a Tax Case: Choice of Forum: $A$ Checklist of Points to Consider, N.Y.U. 22D Inst. oN FED. TAX 75 (1964).

${ }^{3}$ For example: the Court of Claims uses an unustual trial commissioner factfinding procedure; a jury trial is available only in a district court; persons other than lawyers may be admitted to practice before the Tax Court; discovery procedures differ among the courts; the taxpayer is charged interest on unpaid deficiency assessments when he litigates in the Tax Court.

4 Gannett, supra note 2, at 88-90.

5 See Traynor, Administrative and Judicial Procedure for Federal Income, Estate, and Gift Taxes-A Criticism and a Proposal, 38 Colum. L. REv. 1393, 1402-04 (1938).

6 Russell Mfg. Co. v. United States, 175 F. Supp. 159 (Ct. Cl. 1959). BuLl. 46.

7 Treas. Reg. 111, §29.23(p)-11 (1943), as amended, T.D. 5666, 1948-2 CuM.

8 To be "qualified" for various tax advantages presently provided by $\$ \$ 402-04$ of the INT. REv. CODE of 1954, a profit sharing plan must benefit a certain percentage of employees and not discriminate in favor of officers and other highly compensated personnel. INT. Rev. CODE OF 1954, § 401.

9 Rev. Rul. 59-383, 1959-2 CuM. Bull. 456. 
correct. ${ }^{10}$ Since all informed taxpayers in future disputes with the Service on this same point would probably choose to litigate in the Court of Claims, whose decisions are reviewable only by the Supreme Court, the chance that there would soon develop a conflict of decisions among the courts of appeals and the Court of Claims on the correctness of the Regulation was small and, in consequence, it was unlikely that the Supreme Court would grant certiorari in a case involving the Regulation. ${ }^{11}$ In an effort to create a conflict of decisions so that the Supreme Court would be more likely to grant certiorari and uphold the Regulation, ${ }^{12}$ the government filed suit in the District Court for the District of Connecticut to recover the tax refunded to Russell on the years not involved in the prior Court of Claims litigation. The government's theory was that the tax was "erroneously refunded" and therefore recoverable under section 7405(b) of the Internal Revenue Code of $1954 .^{13}$

The Second Circuit, affirming the district court, denied the government a recovery. ${ }^{14}$ Since Judge Friendly, speaking for the court, was not persuaded that the Court of Claims' decisions were incorrect, and since the Service had not made the refund because of a misapprehension of either law or fact, he reasoned that the government had not made a "mistake" (which he equated with the statutory phrase "erroneously refunded") and, therefore, had not satisfied its burden of proving that the taxpayer had money which ex aequo et bono he ought not to retain..$^{15}$

This reasoning may have significant implications for refund suits brought by taxpayers. When a taxpayer finds that the precedents in one court are unfavorable and he deliberately pays a disputed assessment in order to sue for his refund in a court with more advantageous precedents, he does not make a "mistake" any more than did the Service in Russell. Furthermore, it is common for the same taxpayer who loses in one court to win a refund on other years or separable transactions, as the government attempted to in Russell, by arguing an identical legal theory to a

10 Mississippi River Fuel Corp. v. United States, 314 F.2d 953 (Ct. Cl. 1963).

11 The reluctance of the Court to grant certiorari until a conflict develops, and the consequent delay in obtaining an authoritative construction of the law, have at various times prompted proposals for reform. E.g., Del Cotto, The Need for a Court of Tax Appeals: An Argument and a Study, 12 BufFalo L. REv. 5 (1962); Griswold, The Need for a Court of Tax Appeals, 57 HARv. L. REv. 1153 (1944).

12 United States v. Russell Mfg. Co., 349 F.2d 13, 17 n.4 (2d Cir. 1965).

13 Any portion of a tax imposed by this title which has been erroneously refunded (if such refund would not be considered as erroneous under section 6514) may be recovered by civil action brought in the name of the United States.

INT. REv. CoDE of 1954, \$7405(b). Section 6514 defines as erroneous refunds made after expiration of the statutes of limitations. These are recoverable under $\$ 7405(\mathrm{a})$. 14 United States v. Russell Mfg. Co., 349 F.2d 13 (2d Cir.), affirming 245 F. Supp. 159 (D. Conn. 1965).

$15 \mathrm{Id}$. at 16-18. The government's alternative argument that the Service had been mistaken with reference to the application of collateral estoppel to the years not involved in the Court of Claims litigation was also rejected because, assuming there had been such a mistake, it had not induced the refund and was therefore inconsequential. Id. at 18-19. 
second court. ${ }^{16}$ If factors other than an independent consideration of the application of the revenue statutes to the transaction are applied to determine whether the taxpayer is entitled under these circumstances to a refund, the taxpayer's choice of courts may be considerably restricted.

In the area of taxation where statutes usually are controlling, the statutory law relevant to the recovery of overpayments made by either the government or the taxpayer makes only narrow changes in the common law action for money had and received, in which the plaintiff carries the burden of proving that the defendant has money which ex aequo et bono he ought not to retain. Section 7405, as Judge Friendly observed, ${ }^{17}$ was intended merely to limit the number of years in which the government could bring an action to recover erroneous payments from the Treasury, since without such a specific statutory provision the statute of limitations would not run against the sovereign. The Internal Revenue Code provisions relevant to taxpayer refund suits consist merely of conditions precedent to suit ${ }^{18}$ that do not fundamentally modify the common law action. Although the language of the statute conferring jurisdiction on the Court of Claims and the district courts in revenue suits appears to grant taxpayers a blanket right to recover any erroneous or excessive payment, ${ }^{10}$ the section was intended merely as the consent of the sovereign to be sued. ${ }^{20}$ Thus, to recover a refund the taxpayer is required to prove, just as the government was in Russell, that the defendant has money which ex aequo et bono it ought not to retain.21 Until now, courts determining this question have been concerned primarily with whether the payment was required under a proper construction of the revenue statutes. ${ }^{22}$ Judge Friendly thought that under the facts of Russell other considerations also were relevant.

Among the factors that Judge Friendly apparently thought relevant was the Internal Revenue Service's full knowledge at the time of making

${ }^{10}$ E.g., compare Ryman v. Tomlinson, 56-2 U.S. Tax Cas. 79741 (S.D. Fla. 1956), with Harold E. Ryman, 12 CCH Tax Ct. Mem. 1093 (1953).

17349 F.2d at 16.

18 Owen v. United States, 277 F.2d 790 (9th Cir. 1960) (per curiam) ; Sullivan v. United States, 142 F. Supp. 614 (E.D. Pa. 1956).

1928 U.S.C. $\$ 1346$ (a) (1) (1964) :

The district court shall have original jurisdiction, concurrent with the Court of Claims, of:

(1) Any civil action against the United States for the recovery of any internal-revenue tax alleged to have been erroneously or illegally assessed or collected, or any penalty claimed to have been collected without authority or any sum alleged to have been excessive or in any manner wrongfully collected under the internal-revenue laws ....

20 The Congressman who introduced the statute explained that it was designed to provide an action against the United States where a common law action against the Collector was impossible. 61 CoNG. REc. 7506-07 (1921) (remarks of Mr. Jones).

21 Stone v. White, 301 U.S. 532, 534-35 (1937) ; Lewis v. Reynolds, 284 U.S. 281, 283 (1932); United States Paper Exports Ass'n v. Bowers, 80 F.2d 82, 84-85 (2d Cir. 1935); United States v. Jefferson Elec. Mfg. Co., 291 U.S. 386, 402-03 (1934) (dictum).

22 See BitTker, Federal Income, Estate and GIFT Taxation 23-28 (1964); Brabson, Federat Taxation: Basic Principles and Procedures 18 (1965). 
the refund of all the facts and of the conflict of its belief that Russell was not entitled under the Regulation to the deduction with the law as announced by the Court of Claims. ${ }^{23}$ Although this contrasts nicely with the usual definition of mistake, ${ }^{24}$ it should not alone be sufficient to establish that the plaintiff has no right to recover. Mistake, or the absence of it, has no independent significance in actions for restitution, but is relevant only insofar as it bears on the equity of permitting the defendant to retain the payment made by the plaintiff. ${ }^{25}$ Although at common law it was not thought inequitable for the recipient to retain a payment made voluntarily with full knowledge of the facts and in the belief that it was not due, ${ }^{26}$ the government was allowed to recover such voluntary payments. ${ }^{27}$ Taxpayers have been given the same right by statute. ${ }^{28}$ Thus neither the government nor the taxpayer should be barred from recovering simply because at the time of payment it knew all the facts and was aware of its legal position that the payment was not due..$^{29}$

In Russell the absence of mistake might have been thought significant because it enabled the government to shop for precedents. Judge Friendly observed that there would have been no equity in the suit if the government had deliberately made the refund in order to bar Russell from the Court of Claims.30 The unspoken premise was that precedent shopping by the government is inequitable.

23 See 349 F.2d at 17.

24 E.g., Restatement of Restitution \$6 (1937): "Mistake means a state of mind not in accord with the facts."

25 See, e.g., Northrop's Ex'rs v. Graves, 19 Conn. 548, 553-61 (1849) ; Appleton Bank v. McGilvray, 70 Mass. 518, 522 (1855); Moses v. Macferlan, 2 Burr. 1005, 1012, 97 Eng. Rep. 676, 680-81 (K.B. 1760).

26 Keener, QUasi-Contracts 26-27 (1893).

27 Hunter v. United States, 30 U.S. (5 Pet.) 173, 187-88 (1831).

28 INT. REv. CODE of $1954, \S 7422$ (b) : "Such suit or proceeding may be maintained whether or not such tax, penalty or sum has been paid under protest or duress." If the mistake argument of Russell were applied to bar taxpayers from recovering deliberate overpayment in spite of this statute, the development would have its parallel in a similar Pennsylvania experience. The Pennsylvania Supreme Court's narrow construction of a state statute with language similar to both $\$ 7422(\mathrm{~b})$ and 28 U.S.C. $\S 1346$ (a) (1) (1964), however, evoked a prompt corrective response from the Pennsylvania legislature. Compare $\mathrm{Pa}$. Laws 1943, act 162, §\$1-2 (compelling refund of tax "erroneously or inadvertently paid"), construed in Pittsburgh Coal Co. v. Forward Township School Dist., $366 \mathrm{~Pa}$. 489, 78 A.2d 253 (1951), to include only tax paid under a mistake of fact, and in Jefferson Memorial Park v. West Jefferson Hills School Dist., $397 \mathrm{~Pa} .629,156$ A.2d 861 (1959), to exclude deliberate payments, with PA. STAt. ANN. tit. 72, §5566(b), (c) (Supp. 1965) (compelling refund of any tax "paid . . voluntarily or under protest ... to which the political subdivision is not legally entitled....").

29 Of course this may be one of the constituent elements of an estoppel. See generally Lynn \& Gerson, Quasi-Estoppel and Abuse of Discretion as Applied Against the United States in Federal Tax Controversies, 19 TAX L. REv. 487, 488-89 (1964). On the facts of Russell, however, other elements essential to an estoppel were absent. No detrimental reliance on the finality of the refund was shown. Even if it had been shown, it is arguable that it was not justifiable since the statute of limitations implies that an action to recover a refund may be brought within the prescribed period. Moreover, an estoppel is applied only reluctantly against the government. Id. at 489-92; Maguire \& Zimet, Hobson's Choice and Similar Practices in Federal Taxation, 48 HARV. I. REV. 1281, 1299-1310 (1935).

30349 F.2d at 17. 
A recovery which results from the careful choice of a favorable court to decide the case may at first seem difficult to justify, but such pre-trial strategy is an everyday occurrence. ${ }^{31}$ In the tax area, precedent shopping appears to be a natural consequence of the court system established by Congress. Congress must have understood that the several independent courts to which it granted jurisdiction in revenue suits would develop and follow their own precedents. Furthermore, although the mere existence of several independent courts may not compel the inference that Congress intended the litigants to have a conscious choice of precedents, the taxpayers' notorious exercise of this choice ${ }^{32}$ without objection suggests that it is not an accidental characteristic of the system. ${ }^{33}$

If the argument that Congress either built precedent shopping into the court system or has ratified it by long continued acquiescence is rejected and precedent shopping is considered inequitable when practiced by the government, then it also should be inequitable when practiced by a taxpayer. There is no indication in the statutes that taxpayers should have the exclusive right to shop for precedents. ${ }^{34}$ Thus, if the decision in Russell rested on the inequity of government precedent shopping, a taxpayer also might be barred from recovering a refund whenever he deliberately paid a disputed assessment for the purpose of choosing a forum more favorable than the Tax Court. To force cases into the Tax Court in this manner may be desirable because of the special expertise of that tribunal and because a somewhat greater uniformity in the application of the tax laws could be expected ${ }^{35}$ but to restrict the taxpayer's access to other courts would be perilously close to doing that which Congress in the past has considered and rejected. ${ }^{36}$

On the other hand, allowing both the government and the taxpayer to shop for precedents would neither distort the system of independent courts nor deprive the taxpayer of access to the different courts with their special features. In addition, the government would not have an unreasonable advantage. The taxpayer would have the first choice, built into the system, of resisting the deficiency in the Tax Court; only if he chose to pay could the government make a refund and sue for its recovery in an

31 See, e.g., Van Dusen v. Barrack, 376 U.S. 612 (1964) (federal diversity jurisdiction). The plaintiff, of course, has his choice of state law whenever the defendant can be sued in more than one jurisdiction.

32 Traynor, Administrative and Judicial Procedure for Federal Income, Estate, and Gift Taxes-A Criticism and a Proposal, 38 Colum. L. REv. 1393, 1403-04 (1938).

33 The "re-enactment doctrine" is based on similar logic. Cf. National Lead Co. v. United States, 252 U.S. 140, 145-46 (1920); Korth v. Mountain City Copper Co., 174 F.2d 295, 297 (10th Cir. 1949).

34 See Southern Md. Agricultural Ass'n v. United States, 16 F.R.D. 100, 102 (D. Md. 1954).

35 This would be so because, although decisions of the Tax Court are appealable to all the courts of appeals, only a relatively small number of cases actually are appealed. See Bittrer, Federal Income, Estate and Gift Taxation 904 (1964).

36 Compare H.R. REP. No. 1, 69th Cong., 1st Sess. 13-14 (1925), with H.R. ReP. No. 356, 69th Cong., 1st Sess. 48 (1926). 
appropriate district court. ${ }^{37}$ Thus the taxpayer would still be able to elect a jury trial and to save interest charges. The benefits of precedent shopping itself would be divided, the taxpayer having the initial choice while the government could exercise its option to choose a favorable district court only after the taxpayer elected not to resist the deficiency in the Tax Court. This seems more reasonable than permitting taxpayers alone to shop for precedents. While taxpayers use this advantage solely for their selfish interests, the Internal Revenue Service could use precedent shopping, as it attempted to in Russell, to aid in administering the tax laws. Even if the purposes for which the Service chose to shop for precedents were unreviewed by the court, there is no reason to believe that this power would be used irresponsibly. As the agency established by Congress to administer the tax laws, the Internal Revenue Service is not out to squeeze the last drop of revenue from the public; it should, and probably does, ${ }^{38}$ use its power fairly to give effect to Congress' choice of transactions to be taxed and its method of taxing them. Since it would not unfairly disadvantage taxpayers to permit the government to share with them the benefits of precedent shopping, there is no reason which compels the courts to confer on taxpayers the exclusive right to shop for precedents-an advantage which Congress has not seen fit to confer by statute.

Thus, not only is the absence of mistake inconclusive of whether there is a right to restitution, but also the presence of precedent shopping, practiced by either the government or a taxpayer, is consistent with both a reasonable system of adjusting tax liability and with the statutory framework provided by Congress-prohibiting precedent shopping or permitting its practice only by taxpayers is not.

The reference to mistake and precedent shopping in Russell was actually unnecessary in determining whether the taxpayer should have retained the refunds. In his opinion Judge Friendly stated that if he were persuaded that the Court of Claims decisions rejecting the Regulation were incorrect the government would have been entitled to recover. ${ }^{39}$ This is not significantly different from the approach generally followed of determining whether the defendant has money which ex aequo et bono he ought not to retain by asking whether the tax is due under a proper construction of the revenue statutes. ${ }^{40}$ In Russell no more was necessary.

In fact it was unnecessary even to make an exhaustive inquiry into the correctness of the Court of Claims decisions. Although relitigation

37 Under the venue provisions of the Judicial Code, 28 U.S.C. $\$ 1391$ (b), (c) (1964), this would be in the judicial district where the taxpayer resides if he is an individual, or in the judicial district where a corporate taxpayer is "incorporated or licensed to do business or is doing business."

38 Lynn \& Gerson, Quasi-Estoppel and Abuse of Discretion as Applied Against the United States in Federal Tax Controversies, 19 TAX L. REv. 487, 489 (1964).

39349 F.2d at 17.

40 See authorities cited note 22 supra. 
of the same controversy involving the same taxpayer probably is not foreclosed by collateral estoppel if the prior suit dealt with different years or separable transactions, ${ }^{41}$ the prior decision at least inclines the same court toward a determination consistent with its own precedent. Moreover, the prior decision may well have enhanced persuasiveness for another independent court deciding the tax consequences of an essentially identical transaction involving the same parties. ${ }^{42}$ This may explain why Judge Friendly conspicuously deferred to the reasonableness of the Court of Claims decisions, and dismissed the question of the correctness of the Regulation simply by noting that the statutory language appeared to support Russell's right to the deduction. ${ }^{43}$ Thus, although a review of the issue is not completely foreclosed by collateral estoppel, a lawsuit initiated by either a taxpayer or the government may be unlikely to succeed if it is based on the same theory rejected in a prior suit between the same parties. ${ }^{44}$ Where the taxpayer involved has not litigated the issue and the court has no precedent on point, the decision of another court will have no more than ordinary persuasiveness. Thus, if the government were to pay a refund claim based on the invalidity of the disputed Regulation to another taxpayer who had never before litigated the point and were then to bring suit for its recovery in a court which had not before decided the issue, it should be entitled to a decision based on an independent interpretation of the statute and not on the presence or absence of "mistake" or on the supposed inequity of precedent shopping.

Since the decision in Russell might have been based on statute and precedent, it is regrettable that the opinion introduced unnecessarily broad grounds, with import in areas far beyond the case before the court and bound up with history and practice it never considered.

41 Commissioner v. Sunnen, 333 U.S. 591, 601 (1948); Developments in the Law -Res Judicata, 65 HARv. L. REv. 818, 943-44 (1952). Contra, United States v. Russell Mfg. Co., 349 F.2d 13, 18-19 (2d Cir. 1965) (dictum).

42 Some courts of appeals feel that the need for national uniformity in the tax laws is sufficient reason to adopt the reasonable interpretation of another circuit. Goodenow v. Commissioner, 238 F.2d 20, 22 (8th Cir. 1956); Commissioner v. Moran, 236 F.2d 595, 596 (8th Cir. 1956); Grimland v. United States, 206 F.2d 599 (10th Cir. 1953).

43349 F.2d at 16-17.

44 Branscomb, Collateral Estoppel in Tax Cases: Static and Separable Facts, 37 Texas L. Rev. 584, 595-96 (1959). 